原著

\title{
Buerger 病の血管病変に関する組織学的検討
}

\author{
黒 住 武 史* 田中健 蔵* \\ 草 場昭** 勝 村 達 喜***
}

\section{はじめに}

Buerger 病は, 1908年に Leo, Buerger により, Thrombo-angiitis obliterans (以下 TAO と略す) と して報告されて以来1)，その disease entity に関して は多くの論争があり, 否定的な見解もあって未だ定説 はな(2)3). Buerger 病の診断基準としては, 臨床的 所見が重要であり, 病理学的には, 臨床的に Buerger 病あるいはその可能性がある症例より切除された血管 の病理組織像から, はじめて TAO と診断しうる clinico-pathological disease entity に属するものとさ れている. しかし, Buerger病を一つの disease entity として考えるならば, 病理組織学的特徵を確立して, 通常の血栓症や閉塞性動脈硬化症とは鑑別しうる診断 基準が必要である. この様な観点から, 我々は, 臨床 的に Buerger 病あるいはその可能性がある症例より 切除された血管および閉塞部末梢血管について, 組織 学的, 電顕的に検討し, 若干の知見をえたので報告す る.

\section{I. 材料亡方法}

臨床的に Buerger 病と診断された症例27例, およ びその可能性があるもの 6 例より切除された血管につ いて, H.E., Elastica van Gieson および Azan 染色 を行い，その中の 7 例については血管を輪切りと縦切 りにして検討した. さらに 2 例の下腿および 3 例の手 指切断例について, 閉塞部末梢血管を電顕的に観察し た.

\section{II. 結 果}

臨床的に Buerger 病あるいはその可能性がある症 例から切除された血管33例について検討した結果，お

* 九州大学医学部病理

**九州大学医学部第二外科

$* * *$ 岡山大学医学部第二外科
のおのの症例の所見には多様性はあるが，一応従来よ り TAO として記載されている所見に一致するものが 22例あった.

一般に内膜の線維性肥厚部に一致して閉塞性血栓が みとめられ，一部の例では血栓内に好中球浸潤を伴う ものもあった．また毛細血管に富む器質化過程がみら れ, 中膜の平滑筋細胞は肥大し, 外膜より中膜にかけ て栄養血管の拡張, 増生が著明なものがあった. 閉塞 性血栓には, 器質化がす寸むと, リンパ球浸潤, へモ ジデリン沈着がみられた.この様な例では, 中膜にも リンパ球浸潤と共に線維化がすすみ，平滑筋細胞は分 布が疎となる（図１）。また外膜に慢性炎性細胞浸潤 を伴ら線維化のみられる例もあった。

器質化血栓内の毛細血管は, 中膜の拡張した栄養血 管と連絡しているものもあり, 器質化血栓内に筋層を 有する小動脈がみられるものもあった.

さらに, 翏原化が高度で, リンパ球浸潤がほとんど みとめられないものもあり, 中膜, 外膜の線維化が著 明なものもあった.

縦切りの切片で検索すると, 一つの動脈で新鮮な血 栓形成から陳旧化した器質化血栓まで多彩な所見を示 していた.

$\mathrm{TAO}$ の所見として, 血栓内に多核巨細胞や類上皮 細胞の出現が記載されているが，今回検索した範囲内 ではみとめなかった。

以上のように, 今回の検索例には TAO の組織学的 所見として記載されている所見がみられたが，その一 つ一つをみると TAOを独立疾患として認めるにたる 特異的病変とは考え難かった.

さらに上述の所見以外に次のような所見をみとめた.

1. 内弾性板には断裂, 重複がみられ, さらに22例中 4 例に, 重複, 断裂した内弾性板に一致し, あるい は中膜筋層内に巣状の小石灰沈着をみとめた(図2).

2. 中膜筋層は, 新鮮な血栓性閉塞部では肥大し, 平 滑筋細胞由来と考えられる細胞や, 多核巨細胞が巣 


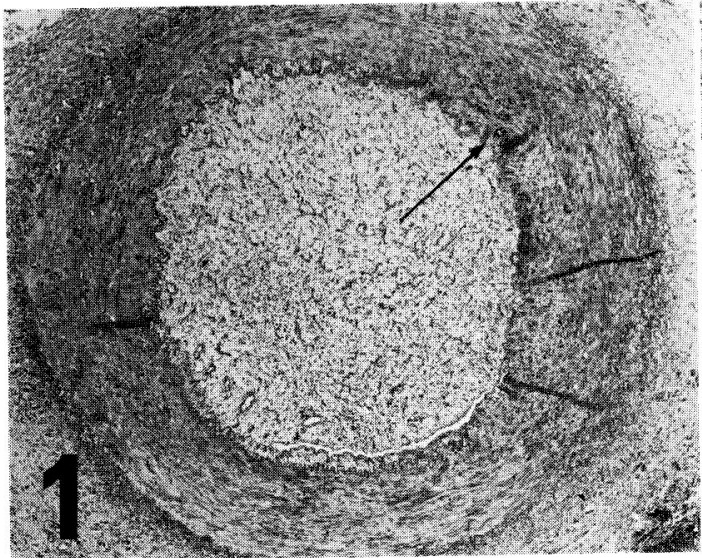

図1リンパ球浸潤を伴う血柽の器質化，中膜および外膜 の線維化がみられ，一部の内弾性板に一致して小 石夾沈着がみられる (矢印). H.E染色. 23倍.

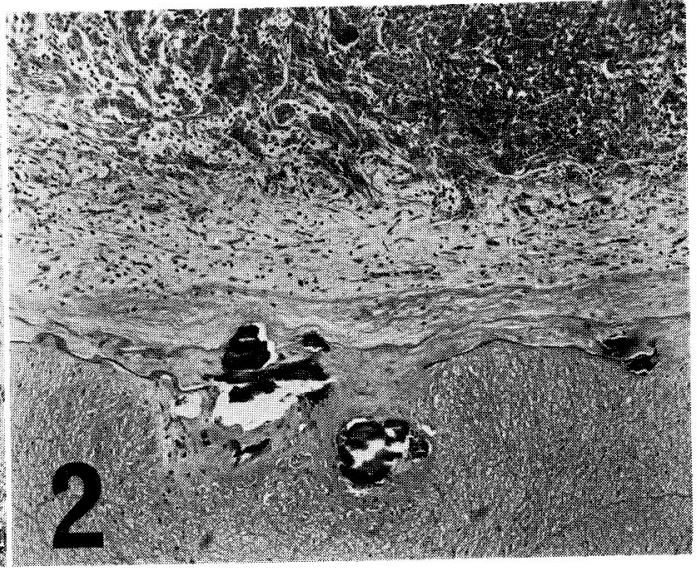

図 2 重複，断裂した内弾性板に一致し，あるいは中 膜筋層内に巣状の小石灰沈着をみとめる. H.E 染色.72倍.

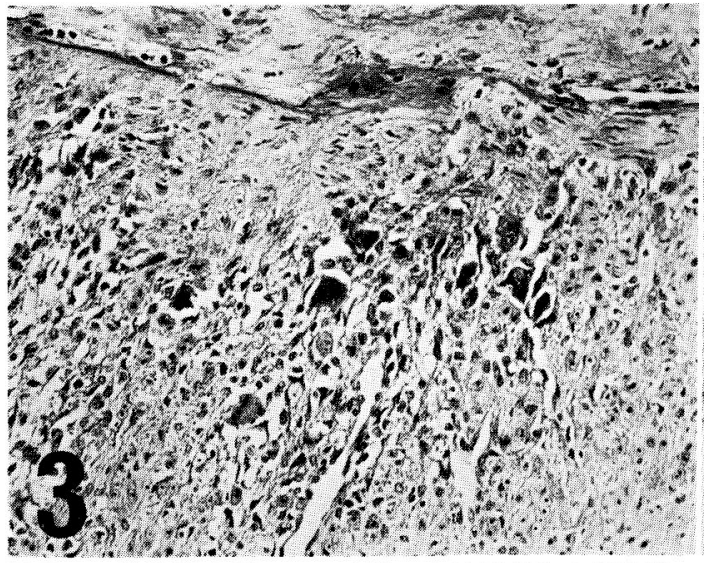

図 3 血栓性閉塞部では, 中膜に多核巨細胞の增生巣 をみとめる. H.E染色. 200 倍.

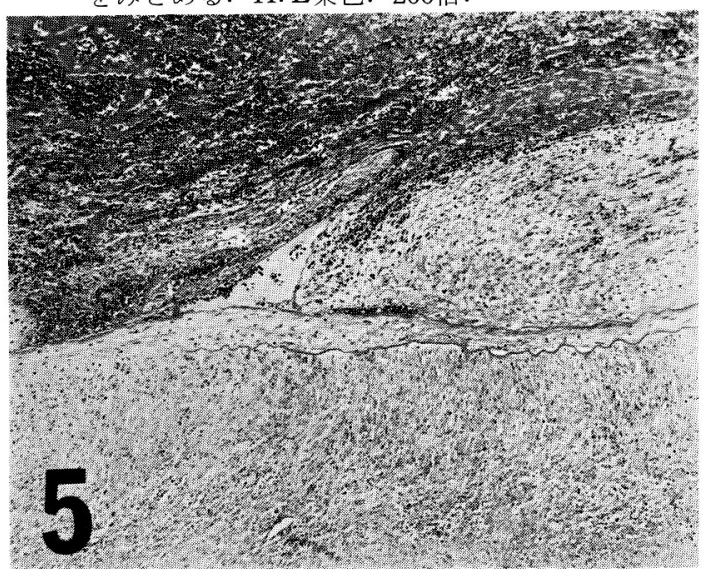

図 5 血栓性閉塞部では,内膜の線維性肥厚をみとめる。 58 倍.

状に増生した例がみられた（図3）.

3. 血栓性閉塞部を縱切りで検索すると, 内膜の線維

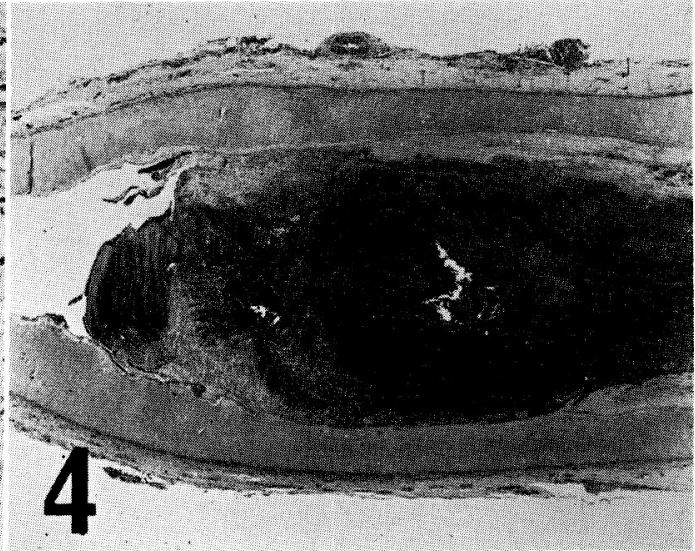

図4血栓性閉塞部では, 内膜の線維性肥厚をみとめ る. 9 倍.

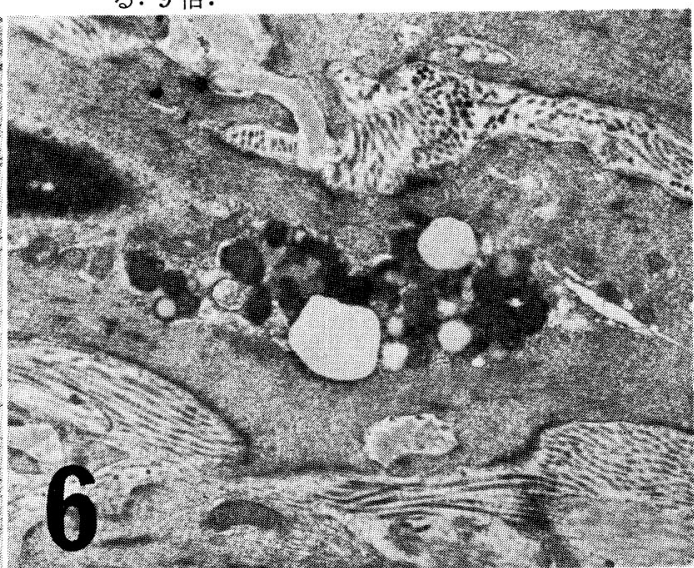

図6 中膜の平滑筋細胞内に lipofuscin がみられる. 8,000 倍.

性肥厚巣がしばしばみられた（図 4，5）.また新鮮 血栓付着部で, 肥厚内膜がめくれて内弾性板が露呈 
し，血栓と接する所見がみられた。

\section{電子顕微鏡的観察}

3 例の手指切断例について, 閉塞部末梢の血管を電 顕的に検索した結果では, 器質化血栓で毛細血管の新 生がみられる部分では, 豊富な organellaや filament をもつ平滑笳細胞由来の細胞が増生し, 一部では細隙 を形成しつつある所見がみられた．また血栓性閉塞部 の中膜には，平滑筋細胞内に lipofuscin がみられるも カがあった（図6）.

\section{III. 考按}

Buerger 病は1908年に Leo, Buerger によりTAO として報告されて以来1), その disease entity として の独立性に関しては未だに論争のあるところで, 否定 的な見解もあり，Fisher2）は血栓症を伴う動脈硬化と し, また Wessler3) によれば, 動脈硬化症や末梢動脈 血栓症と区別すべき点はなく, TAO といら病名は用 いるべきでないと主張している.さらに Gore4) は，

TAO は特異的病変ではなく, primary intravascular thrombosis の結果であると述べている.

しかしながら一方，McKusick5) は日本と韓国およ び米国における症例を比較検討し, (1)地域による差が あること，(2)大型血管にはみられず，また石灰化や内 膜肥厚がなく,さらに血管造影の所見が特徴的である こと，(3)組織学的に動脈硬化の所見がないこと，の 3 点を根拠に TAO は一つの独立した disease entity で あると述べている.また $\mathrm{TAO}$ の病変の分布に関して も, 大動脈6) や諸臟器の動脈7) にも同様の病変がみと められたとの報告もあり, 動脈硬化症との異同をめぐ って未だ見解の統一をみな(8)9).

今回は, TAO が果して病理組織学的にも一つの disease entity として存在しらるか, また, その病理 組織学的診断根拠とは何かを確立するために, 臨床的 に Buerger 病あるいはその可能性があると診断され た33例について検討したが，血栓性閉塞部には新旧多 彩な所見がみられ, 新鮮閉塞性血栓部には好中球浸潤 のあるものもあり, またリンパ球浸潤を伴う器質化が みられた. しかし, 動脈壁の炎症性細胞浸潤は, TAO に primary な所見ではなく, 血栓形成に対する反応 とも考えられた.

また, 巨細胞や類上皮細胞の出現は, 新鮮な血栓性 閉塞部でもみられず，一般的に記載されている程頻繁 にみられる所見ではないと思われる.

血栓性閉塞部を縦切りにして観察すると, 内弾性板 の断裂や重複を伴ら内膜の線維性肥厚がかなりの頻度
でみられ，一部では肥厚内膜がめくれて内弾性板が露 呈し, そこに新鮮血栓がみられる例があり, さらに切 断肢において, 中枢側から末梢まで系統的に検索した 症例では血栓性閉塞部の近くに内膜肥厚をしばしばみ とめ, これらの内膜肥厚巣と閉塞性血栓形成との相関 を考える必要がある.

さらに, TAO の初期病変あるいは基礎となりらる 病変をこの様な血管壁ことに内膜の病変の発生に求め ることが必要で, 先行する内膜病変部に二次的に何ら かの機序で血栓が形成されるとも考えられる10).

22例の TAO の中で 2 例に挨いて中膜に多核巨細胞 がみられたが，これは中膜平滑筋細胞の変性に由来す ると考えられ, TAOの発生における喫煙の様な vasomotor agent の影響を示す所見ではないかとも推定さ れる.

また一般的に TAO では，血管壁の石灰化はみとめ られないとされており,それが動脈硬化症と $\mathrm{TAO}$ を 鑑別する一つの所見にもなっているが，今回の検索で は，22例の TAO の中で 4 例において内弾性板あるい は中膜筋層に小石灰化巣をみとめた。これらは喫煙な どによる血管壁の障害 とも考えられるが11)12), 検 索 した範囲内では動脈硬化の所見はみられなかった.

著者は, 家鬼における反覆凝血塊静注実験で, 血栓 形成部に炎症性細胞浸潤がみられ，また線維性内膜肥 厚部に炎症性細胞浸潤を伴う新鮮血栓が形成されるこ とを報告しているが13)，この様なことからも，炎症性 細胞浸潤は TAO に特異な所見とは考元難く, Gore が述べている様に，TAOを primary intravascular thrombosis といら観点から考えると，内膜や中膜の 障害が血栓形成に重要な因子となっていると考えられ る. また家鬼における実験的大動脈血栓症は, やがて 人の弹腫と同様の組織像を呈するようになることから も14), TAO と粥状硬化症との移行を必ずしも否定で きない.

TAO において血栓付着部辺縁や非閉塞部における 内膜や中膜を電顕的あるいは免疫組織化学的方法を用 いて検討し, 動脈硬化や血栓症と対比しながら血栓形 成を惹起する先行病変を追求することが今後の問題と して重要と思われる.

\section{結論}

1. 臨床的に Buerger 病あるいはその可能性がある と診断された 33 例について, 切除された血管を組織 学的に検討した.

2. 従来, TAO として記載されている所見の中で, 
多核巨細胞や類上皮細胞を血栓の中にみとめる所見 は今回の検索例にはなかった。

3. 閉塞性血栓形成部には, 内膜の線維性肥厚あるい は, 内弾性板が露呈した部がみられ，これらの先行 病変が閉塞性血栓形成に重要であると考えられた。

4. 内弾性板の断裂や重複, および内弾性板に一致し, あるいは中膜に小石灰沈着がみられた。また中膜に は多核巨細胞や平滑筋由来の細胞の巣状増生がみら れる例があった。

5. TAO における炎症性細胞浸潤は，血栓症にもみ られること，また陳旧化した例では粥状硬化症との 鑑別が困難であり, 病理組織学的に TAO の診断基 準を確立するためには, 初期病変, ことに閉塞性血 栓形成以前の動脈病変の解析が必要と考えられた.

\section{文献}

1) Buerger, L. :Thrombo-angiitis obliterans: A study of the vascular lesions leading to presenile spontaneous gangrene. Am. J. Med. Sc., 136; 567 580, 1908.

2) Fisher, C. M. :Cerebral thromboangiitis obliterans. Medicine, 36; 169 209, 1957.

3) Wessler, S. et al. : A critical evaluation of thromboangiitis obliterans. The case against Buerger's disease. New. Engl. J. Med., 262; 1149 1160, 1960 .

4) Gore, I. and Burrows, S. : A reconsideration of the pathogenesis of Buerger's disease. Am. J. Clin. Path., 29; 319 330, 1958.

5) McKusick, V. A. et al. : Buerger's disease, A distinct clinical and pathologic entity. JAM
A., 181; 93 100, 1962.

6) Gilkes, R. and Dow, J. :Aortic involvement in Buerger's disease. Brit. J. Rad., 46; 110 114, 1973.

7) Sprunt, T. P. : Thromboangiitis obliterans as a general vascular disease. South. M. J., 27; 698 703, 1934.

8) McPherson, J. R., et al. : Thromboangiitis obliterans and arteriosclerosis obliterans. Clinical and prognostic differences. Ann. Int. Med., 59; 288 296, 1963.

9) Leu, H. J. und Brunner, U. : Zur Pathologischanatomischen Abgrenzung der Thromboangiitis obliterans von der Arteriosklerose. Dtsch. med. Wschr., 98; 158 161, 1973.

10) Ashford, T. P. and Freiman, D. G. : The role of the endothelium in the initial phases of thrombosis. An electron microscopic study. Am. J. Path., 297; 257 274, 1967.

11) Wilens. S. L. and Plair, C. M. : Cigarette smoking and arteriosclerosis. Science, 138; 975 $\sim 977,1962$.

12) Sackett, D. L.et al. : Relation between aortic atherosclerosis and the use of cigarettes and alcohol. An autopsy study. New. Engl. J. Med., 279; 1413 1420, 1968.

13）田中健藏：血栓症. 福岡医誌，59；337～361. 1968.

14) Sumiyoshi, A. et al. : Aortic fibrofatty type atherosclerosis from thrombus in normolipidemic rabbits. Atherosclerosis, 18; 43 57, 1973. 